\title{
Research on Fresh Meat Cold Chain Logistics Service Quality Model Based on Supply Chain
}

\author{
Wei Guochen ${ }^{1}$, Chen Xiaochun ${ }^{1}$, Liu Cai ${ }^{2}$ \\ ${ }^{1}$ Business School, Beijing Wuzi University, Beijing, China \\ ${ }^{2}$ School of Logistics, Beijing Wuzi University, Beijing, China \\ Email address: \\ 327640307@qq.com (Chen Xiaochun), chenxiaochun_77@163.com (Chen Xiaochun)

\section{To cite this article:} \\ Wei Guochen, Chen Xiaochun, Liu Cai. Research on Fresh Meat Cold Chain Logistics Service Quality Model Based on Supply Chain. Journal \\ of Investment and Management. Vol. 5, No. 3, 2016, pp. 17-24. doi: 10.11648/j.jim.20160503.11
}

Received: July 7, 2016; Accepted: July 18, 2016; Published: July 29, 2016

\begin{abstract}
Along with the fast economic development as well as the increase of consciousness for the food safety, the market demand for live fresh food also increases. In recent years, regarding to fresh meat food quality is more and more important in our country, because the special nature of fresh meat, it extremely easy to receive the microorganism pollution to deteriorate. But lack the research on the fresh meat cold chain physical distribution grade of service appraisal system and about the establishment of model. Based on this, the article takes the fresh meat enterprise as the object to determine the service quality evaluation index of fresh meat cold chain logistics, and establishes the corresponding evaluation model according to FAHP. Then according to its actual enterprises to carry out the verification of the model provide feasible theoretical guidance and reference for the enterprise to find and solve problems.
\end{abstract}

Keywords: Cold Chain Logistics, Service Quality, FAHP, Evaluation Model

\section{Introduction}

With the rapid development of economy and the improvement of living standard, the awareness of food safety is increasing, and the demand for fresh meat has changed from quantity to quality. However, in the fierce competitive conditions, competitive advantage is increasingly difficult to establish and maintain, a long-term competitive advantage is hardly been maintained relying solely on products to attract consumers, logistics service quality should be a new direction of fresh meat enterprises to enhance competitiveness. Due to the lack of fresh meat cold chain logistics service quality evaluation system, enterprise is difficult to control the transport quality of meat in cold chain link of the transportation process.

In this paper, we set up the service quality indicators evaluation of raw meat cold chain logistics by using the research method of establishing a proper evaluation index, and establish the corresponding evaluation model and verification in the enterprise by using the method of fuzzy analytic hierarchy. It provides a theoretical basis and practical reference for enterprises to reduce costs and improve the quality of supervision.

\section{Present Research Situations Review}

The aim of the study is to find out the existing problems in the service quality, and point out the way to solve the problem. As a result of scientificity and usability, appropriate service quality evaluation model and method have great significance in ensuring the quality of service level evaluation. On the basis research of the content and the structure of service quality, the domestic and foreign scholars have developed a lot of models and methods to evaluate the quality of service. At present, several models and methods are widely accepted by the academic circles.

\subsection{Perceived Quality of Service Model}

Christian Gronroos created this model. According to the view, customer service is expected to come to their own needs, corporate image and reputation, and corporate marketing communication. After experiencing service, the customer will generally evaluate the service quality from two aspects, the technical and quality, the service output and the functional 
quality. He believes that the image of the enterprise is of great importance, and point out that the corporate image will be in the process of the formation of perceived service quality, the technical quality and functional quality has played a role in filtering. [1]

\subsection{Service Quality Gap Model}

PZB founded the gap model of service quality based on Gronroos research. The model believes that there are five gaps in the process of formatting service quality, respectively: perceived quality gap, gap of quality standard, service delivery gap, marketing communication gap and perceived service quality gap, the perceived service quality gap depends on the magnitude and direction of the other four gaps, enterprises should commit to reduce the other four gaps to improve perceived service quality gap. [2] As shown in Figure 1.

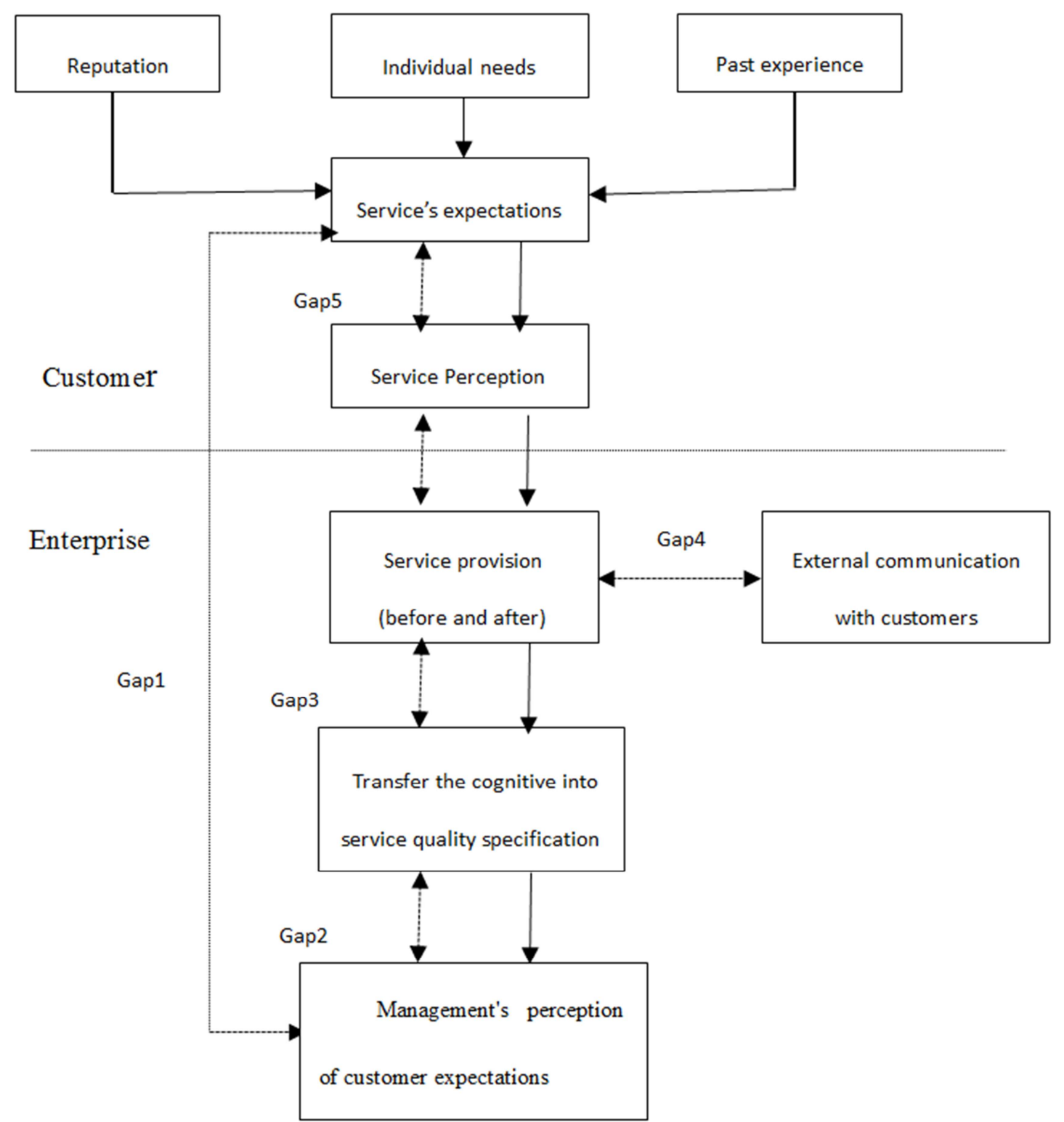

Figure 1. The gap model of service quality.

\subsection{Service Quality Model}

The United States service quality research portfolio establishes this model. According to the point of view, customer perceived service quality is divided into 22 factors; the customer evaluation of service quality mainly depend on the 10 key elements to judge, including tangible, reliability, response, competent skills, etiquette, reliability, security, easy to contact, easy communication and understanding of the customer. With the gradual deepening of the study, the ten factors are reduced to five properties or characteristics: reliability, responsiveness, security, empathy, and tangible. Since then, some scholars have studied whether the service quality model is appropriate for the measurement of logistics services, whether it can be modified with the logistics characteristics. [3] 
Because of our country's research on service quality is insufficient, the selection of the focus is not the same and there is no perfect evaluation index system of logistics service quality. In the research of the domestic scholars, the representative result is the LSQ model established by Zheng Bing and others. [4] The model can evaluate logistics service quality from seven aspects of the quality time, personnel communication quality, order completion quality of goods, transport quality, error handling, flexibility and convenience, the convenience and flexibility is the key factors to evaluation index system of logistics service quality in China.

Some author combine the characteristics of farm produce with its special conditions and equipment and puts forward the comprehensive index system from the perspective of logistics environment, facility and equipment, process and personnel quality. [5] Some research uses various research methods, which combines induction and deduction, logical model and mathematical model, qualitative analysis and quantitative research. It also studies on the present situation of production and consumption of aquatic product in China, the present situation of development of aquatic product cold chain logistics, as well as the functions, the features and the goals of aquatic product cold chain logistics. Meanwhile, it establishes the theoretic framework of performance evaluation and the performance evaluation indexes of aquatic product cold chain. [6] Hou Jieling based on the SERVQUAL model and LSQ (logistics service quality) model, combining with the characteristics of the cold chain logistics service quality in fresh agricultural products, constructs the evaluation index system of fresh agricultural products cold chain logistics service quality under B2C electronic commerce. Then, this pa- per select Tmall mall of the fresh agricultural products cold chain logistics service quality with fuzzy comprehensive evaluation conducted empirical research. [7] Yin Fei sets a cold chain logistics process of a dairy enterprise as an example, make a construction of process assessment system, on the basis of the evaluation index in process priority matrix and the matching degree with these processes and analyzes the cold chain process of the dairy products. After that, uses GO - FLOW safety evaluation method, builds the GO-FLOW picture of a cold chain logistics on dairy products, after the operation of GO method, makes a safety and risk evaluation about dairy key process, and finds out the safety factors and the existing problems influenced the cold chain logistics on dairy products, makes an improvement of these parameters, to distinguish the influence. [8]

From the above literature research, we can find that foreign scholars researches on the service quality are based on cognitive theory of the service quality mechanism, and exploration of the characteristic factors of service quality, establishment of the evaluation model founding on the empirical research results and the detailed analysis of its cause. But domestic scholars mostly focus on empirical research to evaluate the existing model of service quality from a specific industry starting, less theoretically explore characteristic factors of service quality. In addition, the majority of domestic and foreign researches of service quality indicate the perspective of marketing and customer satisfaction. The purpose of research is to realize the high customer satisfaction and retain customers, to achieve the related sales and be recommended by customer. In reality, whether attach to tangible products, service or pure services, the formation of the service quality not only comes from customer satisfaction, but also the agglomeration of the whole production and operation process, we can build a scientific evaluation index system only form the operation process to dig up the factors affect the quality of service.

\section{Evaluation Index}

There are some spontaneous chemical, physical and enzyme catalyzed reactions before Fresh meat consumption, and any link in the process of circulation are likely to be contaminated, although cold chain can reduce the probability of raw meat was polluted and the speed of biochemical reaction, we need to ensure that the fresh meat in cold chain system compliance with the requirements. Only by strengthening the process of cold chain logistics management can we ensure that fresh meat in cold chain system meets the requirements. Fresh meat production enterprises must control product quality from the perspective of the whole cold chain, through monitoring the whole process of product quality to ensure that the output of food quality and safety. Therefore, there is very necessary to study the evaluation index of logistics service quality. [9] According to the investigation and analysis of practical enterprise, evaluation of fresh meat cold chain logistics service quality has three indicators: meat quality, the ability of logistics services and the ability of cold chain logistics services. The paper carries out the analysis from these three indicators.

\subsection{The Quality of Fresh Meet}

In some meat markets and supermarkets, the appearance and the quality of the meat has become an important factor to influence consumer purchasing behavior, according to the experiment and research we can get the influence factors of meat quality is sensory quality, microbial and chemical index.

The fresh meat muscles contain protein and non-protein substances, The nitrogen substances produced by harmful decomposing can cause muscle tissue destruction and color change, produce a rancid smell, and make the surface of the meat sticky. All of these phenomena can be directly evaluated by our sensory organs, such as eyes, nose, mouth (including lips and tongue) and hand, which are sensory quality. Sensory quality can be measured by means of a hydraulic system.

Microbial indicators and chemical indicators are refer to the total number of, bacteria colonies contained in meat, these indicators need to be guaranteed to meet the standard in a certain amount. The total number of colonies and the qualified rate of volatile basic nitrogen can measure microbiological index and chemical index respectively.

\subsection{Logistics Service Ability}

Reasonable evaluation of logistics service quality not only 
to evaluate the results of quality, but also should be able to evaluate the ability of providing the high quality services to the organization. Logistics service capability is a comprehensive index of enterprise logistics level to explore the factors that affect the organization's inherent logistics service capacity, and help us to dig out the organization's own potential and enhance its competitiveness. Personnel factors, equipment facilities, business processes, management systems and environmental factors are the factors that affect the service capacity of the organization.

Personnel factors refer to the evaluation of the employees' consciousness, ability and training situation in the organization. Indicators of evaluation personnel factors are summarized as employee quality, employee quality awareness and employee loyalty. The evaluation index of equipment and facilities is quantity, effective working time capacity of equipment. A good business process not only ensures the satisfaction of internal or external customer and prevents the occurrence of quality problems, but also helps achieving the required quality level. Evaluation of business process is process design, process execution, and process improvement. The management system of an enterprise or organization is mainly embodied in the establishment of the organizational structure, the establishment and implementation of the regulations and rules. The evaluation index of the management system is the ability of organization and management and continuous improvement. Measurement of environmental factors contains the internal environment and external environment of the organization.

\subsection{The Process of Cold Chain Logistics Service}

On the determination of cold chain logistics service process indicators cannot be separated from that of the whole fresh cold chain logistics process. The basic process of cold chain including carcass inspection and quarantine, pre cooling, refrigerated temporary storage; sorting, packaging, distribution and retail market refrigerated show. Through the analysis of the process of the cold chain logistics, we can explore the cold chain logistics process of fresh meat might influence the service quality, and provide the basis for fresh meat cold chain logistics service quality evaluation index to identify. We can conclude that the cold chain logistics service process index including temperature control, timeliness, process safety, customer complaints handling and trace ability of the five indicators through analyze the whole process of cold chain logistics. These five indicators are: temperature deviation and stability, punctuality rate, order completion rate, the rate of complaint handling and traceability.

According to the above identified indicators, evaluation of fresh meat cold chain logistics service quality index system, as shown in Figure 2.

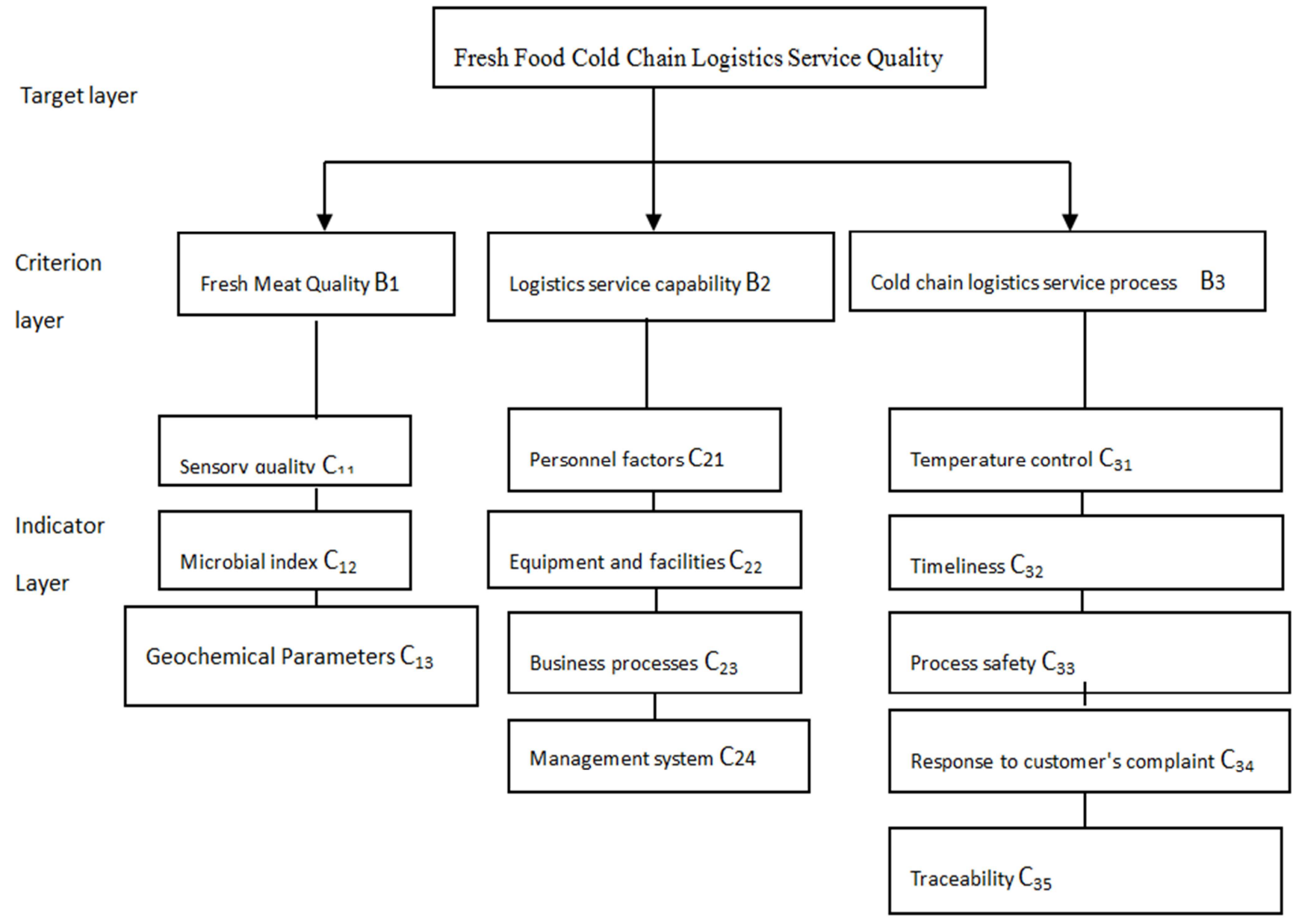

Figure 2. Fresh Meet Cold Chain Logistics Service Quality Assessment index system. 


\section{The Evaluation Model}

This paper is based on the fuzzy analytic hierarchy process (AHP) that is the combination of analytic hierarchy process and fuzzy comprehensive evaluation, Quantitative analysis and qualitative analysis are considered in this method to avoid the uncertainty caused by subjective qualitative judgment, and considering the influence of many factors under the fuzzy environment can solve the fuzzy comprehensive evaluation. [10] The general steps of fuzzy analytic hierarchy process: establishment a hierarchical structure model of evaluation problems and the Construction of fuzzy matrix, need to determine the layers of AHP comparison matrix, determined by calculating the corresponding weight index layers, and then use layers of a fuzzy weights to determine matrix.

First: Establish a hierarchical structure model of evaluation problems. According to the analysis of the problem, to determine the evaluation index, the formation of a target layer - the standard layer of the top-down hierarchical structure of the program model.

Second: Establish a fuzzy judgment matrix. Compare the relative importance of each index of the same level, and use the 1 9 scale method to scale, so as to establish judgment matrix. The indicators scale and meaning as shown in Table 1.
Table 1. The Indicators Scale and Meaning.

\begin{tabular}{ll}
\hline Scale & Meaning \\
\hline 1 & Equal importance \\
3 & One factor is slightly more important than the other one \\
5 & One factor is important than the other one. \\
7 & One factor is significantly more important than the other one \\
9 & $\begin{array}{l}\text { One factor is extremely more important than the other } \\
2,4,6,8\end{array}$ \\
\hline
\end{tabular}

Third: The numerical of judgment matrix is given according to the comprehensive understanding of expert opinion and analysis data. Therefore, it has certain fuzziness and subjective, randomness. So the results of sorting need to verify the consistency. Consistency test index, CI $=(\lambda \max -n) /(n-1)$ means random consistency index RI, as shown in table 2 . When random consistency ratio $\mathrm{CR}=\mathrm{CI} / \mathrm{RI} \leq 0.1$ the judgment matrix is basically in accordance with the random consistency index; when $\mathrm{CR}=\mathrm{CI} / \mathrm{RI}>0.1$ the judgment matrix does not conform the random consistency index, we have to readjust the judgment matrix.

Table 2. Average random consistency index.

\begin{tabular}{|c|c|c|c|c|c|c|c|c|c|c|c|c|c|c|}
\hline Order & 1 & 2 & 3 & 4 & 5 & 6 & 7 & 8 & 9 & 10 & 11 & 12 & 13 & 14 \\
\hline RI & 0 & 0 & 0.52 & 0.89 & 1.12 & 1.26 & 1.36 & 1.41 & 1.46 & 1.49 & 1.52 & 1.54 & 1.56 & 1.58 \\
\hline
\end{tabular}

Fourth: Determine evaluation object set based on based on indicator system determination principles. Let $\mathrm{V}=\{\mathrm{v} 1, \mathrm{v} 2, \ldots$, $\mathrm{Vn}\}$ to describe the evaluation level of each factor state, Is a variety of collection that the evaluator assess the evaluated object. $\mathrm{N}$ represents the number of reviews, generally divided into 3 5 grades, this article is divided into 5 grades, respectively \{high, higher, general, lower, low .

Fifth: Establish fuzzy relation matrix to make fuzzy evaluate for the single factor. Starting from evaluate a single factor to determine the evaluation object of the evaluation set degree of membership which called single factor fuzzy evaluation. First, evaluation the single-factor of factors Ui (i $=1,2, \ldots, \mathrm{m})$, From the factor Ui focus on the evaluation of grade $\mathrm{Vj}(\mathrm{j}=1,2, \ldots \mathrm{m})$, the degree of membership is Rij. In this way, we can get a single factor evaluation set of the $i$ factor Ui: ri= (ri1, ri2,... Rin). $\mathrm{M}$ factors of the evaluation set can be constructed an overall evaluation of the fuzzy relation matrix R.

Sixth: Comprehensive evaluation. By using suitable fuzzy synthesis operator, fuzzy weight vector A and fuzzy relation matrix R are synthesized to obtain the fuzzy comprehensive evaluation result vector of each evaluated object $\mathrm{B}$. Then the comprehensive evaluation results were normalized, multiplied by their degree of membership to get scores, according to the score to evaluate the merits of the object. [11]

According to the above analysis, we can obtain the evaluation of fresh meat cold chain logistics service quality index system AHP structure model as shown in Table 3.

Table 3. Logistics Service Quality Assessment Mode of Fresh Food Cold Chain.

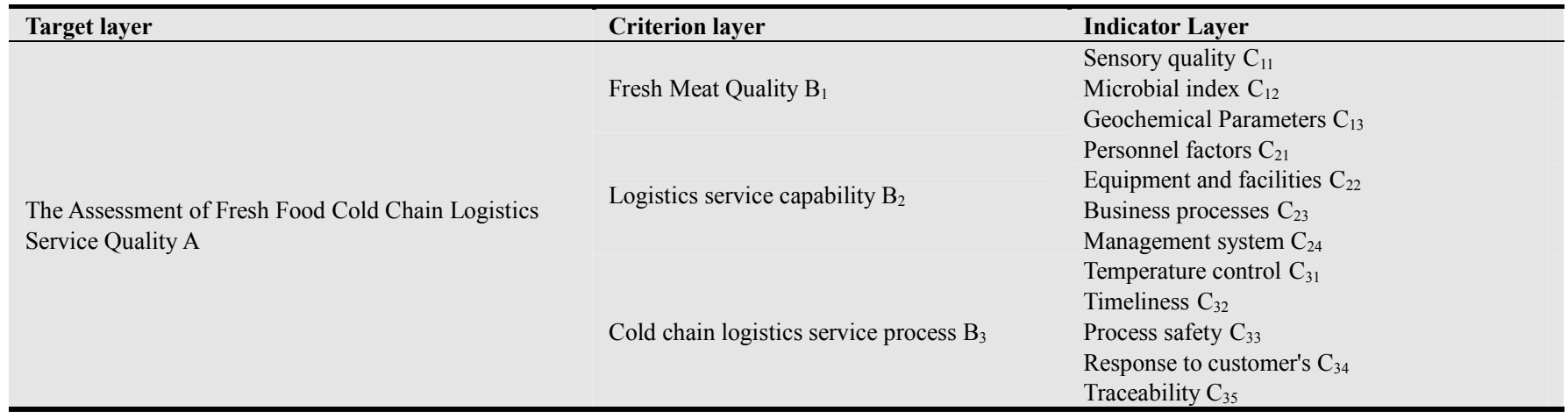




\section{The Validation Model}

In order to verify the feasibility of constructing the model above, we can provide the actual reference to fresh meat cold chain logistics service quality by verified empirically. The following example is analyzed based on a case. Suppose a company $\mathrm{G}$ need to evaluate $\mathrm{A}, \mathrm{B}$ and $\mathrm{C}$ three fresh meat cold chain logistics enterprise service quality, investigative the three enterprises in the three aspects of raw meat quality, the ability of logistics services and cold chain logistics service process, then randomly select 20 employees from the three enterprises to investigation and inquiry. Finally, the score of index as shown in the Table 4.

Table 4. The Logistics Service Quality Evaluation Table of Fresh Meat Cold Chain.

\begin{tabular}{|c|c|c|c|c|c|c|}
\hline Enterprise & $\begin{array}{c}\text { Result } \\
\text { Indicator } \\
\text { Rade }\end{array}$ & High & Higher & General & Lower & Low \\
\hline \multirow{12}{*}{ A } & $\mathrm{C}_{11}$ & 3 & 8 & 6 & 2 & 1 \\
\hline & $\mathrm{C}_{12}$ & 4 & 6 & 8 & 1 & 1 \\
\hline & $\mathrm{C}_{13}$ & 4 & 7 & 5 & 4 & 0 \\
\hline & $\mathrm{C}_{21}$ & 14 & 3 & 2 & 1 & 0 \\
\hline & $\mathrm{C}_{22}$ & 5 & 9 & 3 & 2 & 1 \\
\hline & $\mathrm{C}_{23}$ & 10 & 7 & 2 & 1 & 0 \\
\hline & $\mathrm{C}_{24}$ & 9 & 5 & 4 & 1 & 1 \\
\hline & $\mathrm{C}_{31}$ & 2 & 2 & 5 & 8 & 3 \\
\hline & $\mathrm{C}_{32}$ & 5 & 4 & 7 & 2 & 2 \\
\hline & $\mathrm{C}_{33}$ & 6 & 7 & 3 & 3 & 1 \\
\hline & $\mathrm{C}_{34}$ & 4 & 5 & 8 & 1 & 2 \\
\hline & $\mathrm{C}_{35}$ & 6 & 5 & 6 & 1 & 2 \\
\hline \multirow{11}{*}{ B } & $\mathrm{C}_{11}$ & 4 & 9 & 5 & 1 & 1 \\
\hline & $\mathrm{C}_{12}$ & 7 & 3 & 4 & 5 & 1 \\
\hline & $\mathrm{C}_{13}$ & 5 & 4 & 7 & 2 & 2 \\
\hline & $\mathrm{C}_{21}$ & 12 & 6 & 2 & 1 & 0 \\
\hline & $\mathrm{C}_{22}$ & 8 & 5 & 5 & 1 & 1 \\
\hline & $\mathrm{C}_{23}$ & 9 & 4 & 5 & 1 & 1 \\
\hline & $\mathrm{C}_{24}$ & 10 & 5 & 2 & 2 & 1 \\
\hline & $\mathrm{C}_{31}$ & 6 & 7 & 4 & 2 & 1 \\
\hline & $\mathrm{C}_{32}$ & 7 & 8 & 3 & 1 & 1 \\
\hline & $\mathrm{C}_{33}$ & 13 & 3 & 4 & 0 & 0 \\
\hline & $\mathrm{C}_{34}$ & 10 & 4 & 3 & 2 & 1 \\
\hline \multirow{13}{*}{ C } & $\mathrm{C}_{35}$ & 9 & 8 & 2 & 1 & 0 \\
\hline & $\mathrm{C}_{11}$ & 7 & 5 & 6 & 1 & 1 \\
\hline & $\mathrm{C}_{12}$ & 5 & 9 & 4 & 2 & 0 \\
\hline & $\mathrm{C}_{13}$ & 6 & 7 & 5 & 1 & 1 \\
\hline & $\mathrm{C}_{21}$ & 6 & 7 & 3 & 3 & 1 \\
\hline & $\mathrm{C}_{22}$ & 7 & 5 & 6 & 2 & 0 \\
\hline & $\mathrm{C}_{23}$ & 12 & 5 & 3 & 0 & 0 \\
\hline & $\mathrm{C}_{24}$ & 8 & 7 & 3 & 1 & 1 \\
\hline & $\mathrm{C}_{31}$ & 8 & 3 & 5 & 3 & 1 \\
\hline & $\mathrm{C}_{32}$ & 7 & 5 & 7 & 1 & 0 \\
\hline & $\mathrm{C}_{33}$ & 6 & 9 & 5 & 0 & 0 \\
\hline & $\mathrm{C}_{34}$ & 12 & 5 & 3 & 0 & 0 \\
\hline & $\mathrm{C}_{35}$ & 9 & 6 & 3 & 1 & 1 \\
\hline
\end{tabular}




\subsection{The Establishment of Fuzzy Judgment Matrix}

According to Table 1 to establish the relative importance of the various levels of factors, respectively, compare the importance of each index. According to the questionnaire's results, the various indicators of the fuzzy judgment matrix are as shown in Table 5 - Table 8.

Table 5. The Evaluation Matrix of Fresh Meat Cold Chain Logistics Service Quality.

\begin{tabular}{lllll}
\hline $\mathbf{A}$ & $\mathbf{B}_{1}$ & $\mathbf{B}_{\mathbf{2}}$ & $\mathbf{B}_{\mathbf{3}}$ & $\mathbf{W}_{\mathbf{i}}$ \\
\hline $\mathrm{B}_{1}$ & 1 & $1 / 4$ & $1 / 2$ & 0.3165 \\
$\mathrm{~B}_{2}$ & 4 & 1 & 3 & 0.6250 \\
$\mathrm{~B}_{3}$ & 2 & $1 / 3$ & 1 & 0.2385 \\
$\begin{array}{l}\lambda_{\text {max }}=3.0183, \mathrm{CI}=0.0091, \\
\text { consistency test }\end{array}$ & $\mathrm{RI}=0.52, \mathrm{CR}=\mathrm{CI} / \mathrm{RI}=0.0175<0.1$, pass the \\
\hline
\end{tabular}

Table 6. The Evaluation Matrix of Fresh Meat Quality.

\begin{tabular}{lllll}
\hline $\mathbf{B}_{1}$ & $\mathbf{C}_{\mathbf{1}}$ & $\mathbf{C}_{\mathbf{2}}$ & $\mathbf{C}_{\mathbf{3}}$ & $\mathbf{W}_{\mathbf{i}}$ \\
\hline $\mathrm{C}_{1}$ & 1 & $1 / 5$ & $1 / 5$ & 0.0909 \\
$\mathrm{C}_{2}$ & 5 & 1 & 1 & 0.4545 \\
$\mathrm{C}_{3}$ & 5 & 1 & 1 & 0.4545 \\
$\lambda_{\max }=3.000, \mathrm{CI}=0.0194, \mathrm{RI}=0.52, \mathrm{CR}=\mathrm{CI} / \mathrm{RI}=0.0372<0.1$, pass the \\
consistency test
\end{tabular}

Table 7. The Evaluation Matrix of Logistics Service Capability.

\begin{tabular}{llllll}
\hline $\mathbf{B}_{2}$ & $\mathbf{C}_{\mathbf{4}}$ & $\mathbf{C}_{\mathbf{5}}$ & $\mathbf{C}_{\mathbf{6}}$ & $\mathbf{C}_{\mathbf{7}}$ & $\mathbf{W}_{\mathbf{i}}$ \\
\hline $\mathrm{C}_{4}$ & 1 & 1 & 3 & 2 & 0.3478 \\
$\mathrm{C}_{5}$ & 1 & 1 & 3 & 2 & 0.3478 \\
$\mathrm{C}_{6}$ & $1 / 3$ & $1 / 3$ & 1 & $1 / 3$ & 0.0975 \\
$\mathrm{C}_{7}$ & $1 / 2$ & $1 / 2$ & 3 & 1 & 0.2068 \\
$\lambda_{\max }=4.0604, \mathrm{CI}=0.0201, \mathrm{RI}=0.89, \mathrm{CR}=\mathrm{CI} / \mathrm{RI}=0.0226<0.1$, pass the \\
consistency test
\end{tabular}

Table 8. The Evaluation Matrix of Cold Chain Logistics Service Process.

\begin{tabular}{lllllll}
\hline $\mathbf{B}_{\mathbf{3}}$ & $\mathbf{C}_{\mathbf{8}}$ & $\mathbf{C}_{\mathbf{9}}$ & $\mathbf{C}_{\mathbf{1 0}}$ & $\mathbf{C}_{\mathbf{1 1}}$ & $\mathbf{C}_{\mathbf{1 2}}$ & $\mathbf{W}_{\mathbf{i}}$ \\
\hline $\mathrm{C}_{8}$ & 1 & 3 & 2 & 3 & 2 & 0.3643 \\
$\mathrm{C}_{9}$ & $1 / 3$ & 1 & $1 / 2$ & 1 & $1 / 2$ & 0.1082 \\
$\mathrm{C}_{10}$ & $1 / 2$ & 2 & 1 & 3 & $1 / 2$ & 0.1929 \\
$\mathrm{C}_{11}$ & $1 / 3$ & 1 & $1 / 3$ & 1 & $1 / 2$ & 0.0998 \\
$\mathrm{C}_{12}$ & $1 / 2$ & 2 & 2 & 2 & 1 & 0.2347 \\
$\lambda_{\max }=5.1242, \mathrm{CI}=0.0310, \mathrm{RI}=1.12, \mathrm{CR}=\mathrm{CI} / \mathrm{RI}=0.0277<0.1$, pass the \\
consistency test
\end{tabular}

\subsection{Determine the Weight of Each Factor}

From the above judgment matrix, it can be integrated right index weight levels by seeking $\lambda$ approximation algorithms, and consistent test $\lambda$ combine with random consistency relationship. Through the consistency test to obtain evaluation index weight of the fresh meat cold chain logistics service quality.

$$
\begin{aligned}
& A=(0.3165,0.6250,0.2385) \\
& W_{1}=(0.0909,0.4545,0.4545) \\
& W_{2}=(0.3478,0.3478,0.0975,0.2068) \\
& W_{3}=(0.3643,0.1082,0.1929,0.0998,0.2347)
\end{aligned}
$$

\subsection{Comprehensive Evaluation on Service Quality of Cold Chain Logistics Enterprises}

Taking a company as an example, we can obtain the fuzzy evaluation matrix of a company.

$$
\begin{aligned}
R_{1} & =\left[\begin{array}{ccccc}
0.15 & 0.4 & 0.3 & 0.1 & 0.05 \\
0.2 & 0.3 & 0.4 & 0.05 & 0.05 \\
0.2 & 0.35 & 0.25 & 0.2 & 0
\end{array}\right] \\
R_{2} & =\left[\begin{array}{ccccc}
0.7 & 0.15 & 0.1 & 0.05 & 0 \\
0.25 & 0.45 & 0.15 & 0.10 & 0.05 \\
0.5 & 0.35 & 0.1 & 0.05 & 0 \\
0.45 & 0.25 & 0.2 & 0.05 & 0.05
\end{array}\right] \\
\mathrm{R}_{3} & =\left[\begin{array}{ccccc}
0.1 & 0.1 & 0.25 & 0.4 & 0.15 \\
0.25 & 0.2 & 0.35 & 0.1 & 0.1 \\
0.3 & 0.35 & 0.15 & 0.15 & 0.05 \\
0.2 & 0.25 & 0.4 & 0.05 & 0.1 \\
0.3 & 0.25 & 0.3 & 0.05 & 0.1
\end{array}\right]
\end{aligned}
$$

The assessment indicator of fresh quality, logistics services capacity, cold chain services process A company is:

$\mathrm{B}_{1}=\mathrm{W}_{1} \cdot \mathrm{R}_{1}=(0.195,0.332,0.323,0.123,0.023)$

$\mathrm{B}_{2}=\mathrm{W}_{2} \cdot \mathrm{R}_{2}=(0.473,0.261,0.138,0.068,0.028)$

$\mathrm{B}_{3}=\mathrm{W}_{3} \cdot \mathrm{R}_{3}=(0.212,0.210,0.268,0.202,0.108)$

Fuzzy relation evaluation matrix:

$$
\mathrm{R}_{\mathrm{A}}=\left[\begin{array}{lllll}
0.195 & 0.332 & 0.323 & 0.123 & 0.023 \\
0.473 & 0.261 & 0.138 & 0.068 & 0.028 . \\
0.212 & 0.210 & 0.268 & 0.202 & 0.108
\end{array}\right]
$$

$\mathrm{B}_{\mathrm{A}}=\mathrm{A} \cdot \mathrm{R}_{\mathrm{A}}=(0.385,0.318,0.175,0.130,0.051)$

In the same way, we can obtain the evaluation results of $B$ and $\mathrm{C}$ are:

$\mathrm{B}_{\mathrm{B}}=\mathrm{A} \cdot \mathrm{R}_{\mathrm{B}}=(0.503,0.272,0.103,0.104,0.058)$

$\mathrm{B}_{\mathrm{C}}=\mathrm{A} \cdot \mathrm{R}_{\mathrm{C}}=(0.408,0.264,0.227,0.072,0.030)$

We provide the rat of each grade in $\mathrm{V}$, each element of the quantified value respectively: $\mathrm{V} 1=100, \mathrm{~V}_{2}=85, \mathrm{~V}_{3}=70, \mathrm{~V}_{4}=55$, $\mathrm{V}_{5}=40, \mathrm{~V}=[100,85,70,55,40]^{\mathrm{T}}$, the closer comprehensive value to 100 , the higher fresh meat cold chain logistics service quantity; the closer to 40, the lower quality. The comprehensive value of $\mathrm{A}, \mathrm{B}, \mathrm{C}$ as follows:

$$
\begin{aligned}
& \mathrm{M}_{\mathrm{A}}=\mathrm{B}_{\mathrm{A}} \cdot \mathrm{V}=86.97 \\
& \mathrm{M}_{\mathrm{B}}=\mathrm{B}_{\mathrm{B}} \cdot \mathrm{V}=88.67 \\
& \mathrm{M}_{\mathrm{C}}=\mathrm{B}_{\mathrm{C}} \cdot \mathrm{V}=89.63
\end{aligned}
$$

It can be seen that the fresh meat business prop cold chain logistics service quality evaluation of $\mathrm{C}$ enterprise is better. At the same time, A should strengthen the ability of logistics service, because the weight is relatively large. According to a corporate index score table shows that the cold chain logistics service capacity of A in the temperature control is not very good. Evaluating cold chain logistics service quality provides a realistic basis to improve and optimists cold chain logistics service quality in the future, timely discover their own problems has great significance for the improvements and the development of fresh food enterprises. 


\section{Conclusion}

The paper establishes the fresh meat cold chain logistics service assessment index based on actual investigation and experimental research, and according to the FAHP (fuzzy analytic hierarchy process) to establish the evaluation model. We can get the evaluation result through enterprise actual situation and the model verification, which provide a realistic basis for the improvement of enterprise cold chain logistics service quality to, which has important significance for the development of the cold chain logistics service quality evaluation. Some theoretical hope the future research can provide some reference through the analysis result in this area, a few conclusions have been found to offer reference to the research of inclined-layer placing method. The paper sill has exist some problems in the stage of actual verification, for example, the some indicators of enterprise is unable to carry on the accurate scoring, the measure factors of some indicators cannot be quantitative measurement, which is caused the evaluation step uncertainty and form deviation for the final evaluation of enterprise service quality. Hope that the future research in this area is more perfect.

\section{References}

[1] Gronroos C. A Service Model and its Marketing Implication. European Journal of Marketing, 1984, 04.

[2] Cheng Longsheng. The theory and method of Service Quality Evaluation [M]. Chinese Standard Press, 2011.
[3] Zhang Ningjun. Service Management - based on the quality and capacity of competition research. Economic\& Management Publishing House, 2006.

[4] Zheng Bing, Jin Yufang et al. Establishment of the China's local logistics service quality evaluation index and its experimental verification [J]. Management Review, 2007, 04.

[5] Deng Yanwei. Study on performance evaluation of cold chain logistics of aquatic products in China [D]. Beijing Jiaotong University, 2014.

[6] Song Baoe, Zhu Wenying, Li Xiaoming. The Research on the Assessment of Farm Produce Cold Chain Quality and Safety Based on Fuzzy Comprehensive Evaluation [J]. Journal of food science and biotechnology, 2013, 10 .

[7] Li Lin, Hou Jieling. Study on the service quality evaluation of the cold chain logistics of fresh agricultural products in e-commerce [J]. Logistics technology, 2015, 06: 132-135.

[8] Yin Fei. Safety evaluation of food cold chain logistics [D]. Jiangnan University, 2013.

[9] Chen Hongli, Li Jinying, Liu Yongsheng. The Service Quality of Fresh Food Cold Chain Logistics [J]. Logistics Technology. 2011.

[10] Zhang Jijun. Fuzzy Analytic Hierarchy Process [J]. Fuzzy System and Mathematics, 2002, 02.

[11] Lv Yuejin. Ranking of Fuzzy Analytic Hierarchy Process Based on Fuzzy Consistent Matrix [J]. Fuzzy System and Mathematics 2002, 02. 